\title{
Influence of starches of low digestibility on the rat caecal microflora
}

\author{
By A. K. MALLETT, C. A. BEARNE, P. J. YOUNG AND I. R. ROWLAND \\ British Industrial Biological Research Association, Carshalton, Surrey SM5 4DS
}

AND C. BERRY

Flour Milling and Baking Research Association, Chorleywood, Herts WD3 5SH

(Received 7 January 1988-Accepted 23 June 1988)

\begin{abstract}
1. Male Sprague-Dawley rats were fed on either a purified, fibre-free diet or a diet in which half the maize starch was replaced with uncooked amylomaize or potato starch (equivalent to 100 or $200 \mathrm{~g}$ amylase-resistant starch (ARS)/ kg diet respectively). Changes in short-chain fatty acids (SCFA), pH, ammonia and a number of bacteria! variables in caecal contents were then assessed.

2. Both ARS supplements decreased caecal content $\mathrm{pH}$ by approximately $1-2$ units, with an associated reduction in ammonia concentration. Potato starch significantly decreased the concentration of SCFA in the hindgut, while amylomaize supplementation increased propionic and butyric acids but decreased the occurrence of minor, branched-chain fatty acids.

3. Caecal bacterial biotransformation activities ( $\beta$-glucosidase $(E C$ 3.2.1.21), $\beta$-glucuronidase $(E C$ 3.2.1.31), reduction of $p$-nitrobenzoic acid, apparent ammonia formation) were consistently decreased by both ARS sources.

4. The results demonstrate that amylase-resistant carbohydrate altered toxicologically important functions in the large-intestinal flora of the rat.
\end{abstract}

Fermentable, poorly digested dietary components such as fibre and certain sugars can modify enzymic functions of the large intestinal microflora responsible for the biotransformation of chemical substances to toxic products in the gut (Rowland et al. 1985). The effects of these materials on the flora arise from their resistance to digestion by mammalian intestinal enzymes, allowing the passage of the unchanged carbohydrate into the large intestine (Cummings et al. 1986). The range of dietary components identified as 'resistant' to digestion has increased in recent years, with the observation that a number of natural or processed starches are present in ileal effluent and hence may be liable to bacterial degradation (Englyst \& Cummings, 1985, 1986, 1987). A proportion of this carbohydrate may arise from digestible starch that has not been completely absorbed in the small intestine (Stephen et al. 1983; Englyst \& Cummings, 1985; Flourie et al. 1986) or from amylose which has undergone physical retrogradation during processing and cooking to a form resistant to attack by pancreatic amylase (EC 3.2.1.1) (Englyst \& Cummings, 1985; Berry, 1986; Björck et al. 1986). Such 'resistant starch' also occurs naturally in vegetables and other plant materials (Englyst \& Cummings, 1986, 1987).

The provision of additional fermentable energy by such materials (MacFarlane \& Englyst, 1986; Cummings \& Englyst, 1987) may bring about changes in the concentration or relative species diversity of bacteria in the large intestine, although such effects are generally difficult to measure accurately due to methodological limitations (Moore \& Holdeman, 1975). Microbial enzyme activities, in contrast, can be readily measured and have demonstrated that diet-related changes in the metabolism of many chemicals can lead to toxic-product formation (Rowland et al. 1985). These metabolites may interact directly with target tissues or induce damage following subsequent metabolism by mammalian enzymes, possibly resulting in genotoxic effects (Rowland et al. 1985). Modification of bacterial metabolic activity by diet would therefore appear to be one important environmental factor influencing the disposition of xenobiotic compounds in vivo. 
In the study described here, the effect of uncooked potato starch and amylomaize starch (both 'resistant' types) on selected caecal bacterial biotransformation activities was investigated in the rat. Associated changes in intestinal short-chain fatty acid (SCFA) composition and total bacterial numbers are also reported.

\section{METHODS}

\section{Animals and diets}

Male Sprague-Dawley rats (Harlan-Olac Ltd, Bicester) were purchased at weaning (3 weeks old), randomized on receipt and housed in plastic and stainless-steel grid-bottom cages (without bedding) and given access to food and tap water ad lib. for 3 weeks. Food intake and body-weight gain were recorded every $2-3 \mathrm{~d}$.

The diets comprised either a fibre-free purified control diet containing maize starch (product no. S4126; Sigma Chemical Co. Ltd, Poole, Dorset) as the principal carbohydrate, or experimental diets in which half of the maize starch was replaced with amylomaize starch (Hylon VII; National Starch and Chemical, Manchester), or potato starch (product no. S4521; Sigma) to give a final concentration of $378 \mathrm{~g} / \mathrm{kg}$ diet. The final diet preparations contained $755 \mathrm{~g}$ total starch, $150 \mathrm{~g}$ casein (Sigma), $50 \mathrm{~g}$ maize oil (Mazola ${ }^{(C P C}$ (United Kingdom) Ltd, Esher, Surrey) containing $1 \mathrm{~g} \mathrm{DL}-\alpha$-tocopherol per 1$), 10 \mathrm{~g}$ vitamin mix (Wise et al. 1982) and $35 \mathrm{~g}$ mineral mix (Wise et al. 1982) $/ \mathrm{kg}$ diet base. On the basis of manufacturers' information, both the maize starch and the amylomaize starch contained approximately $750 \mathrm{~g}$ amylopectin and $250 \mathrm{~g}$ amylose $/ \mathrm{kg}$.

The total and amylase-resistant starch (ARS) contents of the three rations, as well as that of the individual starches, were determined by the method of Berry (1986) and represent the contribution of the two starch forms in the uncooked diets, as fed to the rats. Quadruplicate samples $\left(10 \mathrm{mg}\right.$ ) of starches were incubated overnight (approx $17 \mathrm{~h}$ ) at $42^{\circ}$ with continuous shaking with a mixture of 500 units hog pancreatic $\alpha$-amylase $(E C 3.2 .1 .1$; product no. 102814 , The Boehringer Corporation (London) Ltd) and 0.5 units pullulanase (EC 3.2.1.41; product no. 108944, Boehringer) in $0.1 \mathrm{M}$-sodium acetate buffer, pH $5 \cdot 2$, containing $0.004 \mathrm{M}$-calcium chloride. The total incubation volume was $1.0 \mathrm{ml}$. The procedure for recovering undigested starch by precipitation with ethanol was as described by Englyst et al. (1982), and the solubilization of ARS with sequential additions of water and $4 \mathrm{M}-\mathrm{KOH}$ as described by Berry (1986). Solubilized ARS was digested to free glucose using amyloglucosidase (EC 3.2.1.3; product no. 208469 , Boehringer) as described by Englyst et al. (1982), and glucose determined colorimetrically (Test Combination kit 124 028, Boehringer). Glucose was multiplied by 0.9 to convert to ARS.

\section{Preparation of caecal content suspensions}

The animals were killed by carbon dioxide inhalation and a $200 \mathrm{mg} / \mathrm{ml}$ suspension of contents prepared anaerobically in deoxygenated saline $(9 \mathrm{~g}$ sodium chloride/ 1$)$, as described previously (Mallett et al. 1985). For rats fed on the potato-starch-containing diet, approximately $3 \mathrm{~g}$ of the total contents of the caecum were used to prepare the caecal suspension due to pronounced caecal enlargement (see Results). The $\mathrm{pH}$ of the caecal content suspension was then determined using a Radiometer digital $\mathrm{pH}$ meter (model no. PHM62). Non-bacterial debris was sedimented by centrifugation at $500 \mathrm{~g}$ for $3 \mathrm{~min}$, and the supernatant fracton decanted and used immediately for enzyme activity measurements.

\section{Determination of bacterial enzyme activities}

Enzyme activity measurements were performed at $37^{\circ}$ under an atmosphere of nitrogen$\mathrm{CO}_{2}$-hydrogen (100: 10:10, by volume) in glass Bijoux bottles (nominal volume $7.5 \mathrm{ml}$ ) each 
Table 1. Analysis of starches and diets for amylase- (EC 3.2.1.1) resistant starch (ARS) content, expressed on a dry matter basis $(\mathrm{g} / \mathrm{kg})$

(The calculated ARS content of the diets, based on an amylomaize or potato starch content of $377.5 \mathrm{~g} / \mathrm{kg}$, is given in parentheses)

\begin{tabular}{ll}
\hline \multicolumn{1}{c}{ Sample } & ARS \\
\hline Maize starch & 7 \\
Maize-starch diet & 5 \\
Amylomaize starch & 306 \\
Amylomaize-starch diet & $101(116)$ \\
Potato starch & 539 \\
Potato-starch diet & $204(203)$ \\
\hline
\end{tabular}

fitted with a screw cap and rubber septum (Mallett et al. 1985). A $1 \mathrm{ml}$ portion of caecal contents suspension was diluted by adding three vol. sterile, deoxygenated 0.067 M-potassium phosphate buffer (pH 7-2). Caecal bacterial $\beta$-glucosidase $(E C$ 3.2.1.21), $\beta$ glucuronidase $(E C$ 3.2.1.31) and nitrate reductase $(E C$ 1.7.99.4) activities, the reduction of $p$-nitrobenzoic acid (nitroreductase activity) and the formation of ammonia from endogenous caecal precursors were measured as described previously (Mallett $e t$ al. 1985). The concentration of total bacterial cells present in the caecal suspension was determined from a direct microscopic count (Holdeman \& Moore, 1973).

\section{Determination SCFA}

SCFA were separated after diethyl ether extraction of an acidified suspension of caecal contents $(200 \mathrm{mg} / \mathrm{ml})$ in saline. A Pye 104 gas-liquid chromatograph with flame ionization detector and a $2.7 \mathrm{~m} \times 6 \mathrm{~mm}$ o.d. column containing SP1200 (15\%) and phosphoric acid ( $1 \%$ ) on 100-120 chromosorb WAW (carrier gas nitrogen, flow rate $50 \mathrm{ml} / \mathrm{min}$; column temperature $120^{\circ}$, detector $350^{\circ}$ ) was used. Each sample was analysed in duplicate. 3-Methylvaleric acid was used as internal standard and added to the sample before extraction.

\section{Statistical methods}

The experimental values were subject to analysis of variance using the Minitab Statistical Package (Minitab Inc., University Park, Pennsylvania, USA), and significant differences assessed from a comparison of mean values, employing the least significant difference criterion (Snedecor \& Cochran, 1968).

\section{RESULTS}

Analysis of the three starches used in the present study showed that maize starch contained only a trace of amylase-resistant material, whereas the amylomaize and potato starches contained between one-third and half ARS, on a dry matter basis (Table 1). Incorporation of the amylomaize or potato-starch components into the purified diet gave a concentration of 100 or $200 \mathrm{~g} \mathrm{ARS} / \mathrm{kg}$ respectively in the final ration (Table 1). However, while the susceptibility of the carbohydrates to amylase attack differed in vitro, the substitution of amylomaize or potato starch for maize starch was without effect on final body-weight or feed utilization (Table 2).

Both starch supplements resulted in a significant increase in the wet weight of caecal content (amylomaize 3-fold, potato 10 -fold), but the total bacterial numbers per caecum 
Table 2. Final body-weight, weight gain and feed utilization for rats fed on various starchbased diets*

(Mean values and standard deviations for five rats; food consumption and body-weight gain measurements were made every $2-3 \mathrm{~d}$ )

\begin{tabular}{|c|c|c|c|c|c|c|}
\hline \multirow[b]{2}{*}{ Dietary starch } & \multicolumn{2}{|c|}{$\begin{array}{c}\text { Final } \\
\text { body-wt }(\mathrm{g})\end{array}$} & \multicolumn{2}{|c|}{$\begin{array}{l}\text { Wt gain }(\mathrm{g} / \mathrm{rat} \\
\text { per } 3 \text { weeks) }\end{array}$} & \multicolumn{2}{|c|}{$\begin{array}{c}\text { Feed conversion efficiency } \\
\text { (g body-weight gain / } \\
\text { diet eaten) }\end{array}$} \\
\hline & Mean & SD & Mean & SD & Mean & SD \\
\hline Maize & 156 & 9 & 78 & 11 & 0.42 & 0.03 \\
\hline Amylomaize & 156 & 5 & 85 & 5 & $0 \cdot 36$ & 0.03 \\
\hline Potato & 166 & 9 & 87 & 7 & 0.43 & 0.05 \\
\hline
\end{tabular}

* For details, see p. 598.

Table 3. Some caecal variables from rats fed on various starch-based diets $\dagger$

(Mean values and standard deviations for five rats)

\begin{tabular}{|c|c|c|c|c|c|c|c|c|}
\hline \multirow[t]{2}{*}{ Dietary starch... } & \multicolumn{2}{|c|}{ Maize } & \multicolumn{2}{|c|}{ Amylomaize } & \multicolumn{2}{|c|}{ Potato } & \multirow[b]{2}{*}{$F_{2,12}$} & \multirow[b]{2}{*}{$P$} \\
\hline & Mean & $\mathrm{SD}$ & Mean & $\mathrm{SD}$ & Mean & SD & & \\
\hline $\begin{array}{l}\text { Amount of caecal } \\
\text { contents }(\mathrm{g})\end{array}$ & $0 \cdot 7$ & $0 \cdot 1$ & $2 \cdot 5^{* *}$ & $0 \cdot 4$ & $7 \cdot 2^{* *}$ & 0.6 & $63 \cdot 2$ & $* * *$ \\
\hline $\begin{array}{l}\text { Total bacterial col } \\
\log _{10} / g \\
\log _{10} / \text { caecum }\end{array}$ & $\begin{array}{l}10 \cdot 78 \\
10 \cdot 61\end{array}$ & $\begin{array}{l}0.08 \\
0.04\end{array}$ & $\begin{array}{l}10 \cdot 58 \\
10 \cdot 96\end{array}$ & $\begin{array}{l}0 \cdot 16 \\
0 \cdot 18\end{array}$ & $\begin{array}{l}10 \cdot 07^{*} \\
10 \cdot 82\end{array}$ & $\begin{array}{l}0.26 \\
0 \cdot 32\end{array}$ & $\begin{array}{l}4 \cdot 1 \\
0 \cdot 6\end{array}$ & $\stackrel{*}{N S}$ \\
\hline $\begin{array}{l}\text { Ammonia } \\
\mu \mathrm{mol} / \mathrm{g} \\
\mu \mathrm{mol} / \text { caecum }\end{array}$ & $\begin{array}{l}5 \cdot 0 \\
3 \cdot 8\end{array}$ & $\begin{array}{l}1 \cdot 1 \\
1 \cdot 1\end{array}$ & $\begin{array}{l}1 \cdot 6^{*} \\
4 \cdot 4\end{array}$ & $\begin{array}{l}0.5 \\
1.7\end{array}$ & $\begin{array}{l}2-8 \\
19 \cdot 5 * * *\end{array}$ & $\begin{array}{l}0 \cdot 3 \\
1.8\end{array}$ & $\begin{array}{r}5.6 \\
31.9\end{array}$ & * \\
\hline $\mathrm{pH}$ & $7 \cdot 6$ & $0 \cdot 1$ & $6 \cdot 3^{* * *}$ & $0 \cdot 3$ & $5 \cdot 1^{* * *}$ & $0 \cdot 1$ & $53 \cdot 5$ & $* * *$ \\
\hline
\end{tabular}

NS, not significant.

Mean values are significantly different from those for the maize-starch group (ANOVA): ${ }^{*} P<0 \cdot 05$, ** $P<0.01, * * * P<0.001$.

$\dagger$ For details, see p. 598.

remained unchanged despite this enlargement (Table 3). The concentration of microorganisms was, however, significantly decreased in animals fed on the potato-starch diet (Table 3). The $\mathrm{pH}$ of the caecal contents was significantly decreased by both starch supplements, with a corresponding decrease in the concentration of ammonia, although this achieved statistical significance only for the amylomaize-containing diet (Table 3 ). The pronounced caecal enlargement noted with potato starch resulted in a marked increase in total ammonia per caecum (Table 3).

Analysis of the principal SCFA in the hind-gut showed a major re-organization of $\mathrm{C}_{3}$, $\mathrm{C}_{4}$ and $\mathrm{C}_{5}$ components in the two ARS-diet groups. Potato starch significantly decreased the concentration of all SCFA analysed, with no minor SCFA (i.e. isobutyric, valeric and isovaleric) detected (Table 4). Amylomaize starch, in contrast, had no effect on acetate levels in the caecum, and increased propionic and butyric acid contents by approximately $50 \%$; again, however, the minor SCFA components were decreased below the limits of 
Table 4. Concentration of short-chain fatty acids $(S C F A ; m g / g)$ in caecal content from rats fed on various starch-based diets $\dagger$

(Mean values and standard deviations for four rats)

\begin{tabular}{|c|c|c|c|c|c|c|c|c|}
\hline \multirow[t]{2}{*}{ Dietary starch ... } & \multicolumn{2}{|c|}{ Maize } & \multicolumn{2}{|c|}{ Amylomaize } & \multicolumn{2}{|c|}{ Potato } & \multirow[b]{2}{*}{$F_{2,9}$} & \multirow[b]{2}{*}{$P$} \\
\hline & Mean & SD & Mean & SD & Mean & SD & & \\
\hline Acetic & $6 \cdot 9$ & $5 \cdot 4$ & $6 \cdot 2$ & $0 \cdot 6$ & $3 \cdot 8 * * *$ & 0.4 & $5 \cdot 5$ & $*$ \\
\hline Propionic & $2 \cdot 3$ & $0 \cdot 2$ & $3 \cdot 6^{* * *}$ & $0 \cdot 3$ & $1 \cdot 0^{* * *}$ & $0 \cdot 3$ & $22 \cdot 1$ & $* * *$ \\
\hline Butyric & 0.82 & $0 \cdot 64$ & $1 \cdot 58^{* * * *}$ & $0 \cdot 16$ & $0 \cdot 04^{* * *}$ & $0 \cdot 01$ & $49 \cdot 8$ & $* * *$ \\
\hline Isobutyric & 0.16 & 0.01 & ND & - & ND & - & - & - \\
\hline Valeric & 0.24 & $0 \cdot 18$ & ND & - & ND & - & - & - \\
\hline Isovaleric & 0.19 & 0.03 & ND & - & ND & - & $\ldots$ & - \\
\hline
\end{tabular}

ND, not detected (limit $20 \mu \mathrm{g} / \mathrm{g}$ ).

Mean values were significantly different from those for the maize-starch group (ANOVA): ${ }^{*} P<0.05$, *** $P<0.001$.

$\dagger$ For details, see p. 598.

Table 5. Occurrence of total acetic, propionic and butyric acids (mg/total caecum) in the hind-gut of rats fed on various starch-based diets $\uparrow$

(Mean values and standard deviations for four rats)

\begin{tabular}{|c|c|c|c|c|c|c|c|c|}
\hline \multirow[t]{2}{*}{ Dietary starch ... } & \multicolumn{2}{|c|}{ Maize } & \multicolumn{2}{|c|}{ Amylomaize } & \multicolumn{2}{|c|}{ Potato } & \multirow[b]{2}{*}{$F_{2,9}$} & \multirow[b]{2}{*}{$P$} \\
\hline & Mean & SD & Mean & SD & Mean & SD & & \\
\hline Acetic & $6 \cdot 1$ & $4 \cdot 8$ & $12 \cdot 1$ & $2 \cdot 1$ & $25 \cdot 9 * * *$ & $1 \cdot 0$ & $12 \cdot 9$ & $* *$ \\
\hline Propionic & $2 \cdot 0$ & 0.2 & $7 \cdot 3 * *$ & $1 \cdot 8$ & $5 \cdot 8$ & $1 \cdot 1$ & $7 \cdot 3$ & $*$ \\
\hline Butyric & $0 \cdot 7$ & $0 \cdot 1$ & $2 \cdot 8^{* *}$ & 0.2 & $0 \cdot 3^{*}$ & $0 \cdot 1$ & $25 \cdot 6$ & $* * *$ \\
\hline
\end{tabular}

$\mathrm{ND}$, not detected (limit $20 \mu \mathrm{g} / \mathrm{g}$ ).

Mean values were significantly different from the maize-starch group (ANOVA): ${ }^{*} P<0.05,{ }^{* *} P<0.01$, *** $P<0.001$.

$\dagger$ For details, see p. 598.

detection (Table 4). When SCFA content per total caecum was calculated, the amylomaize and potato-starch treatments produced an increase in acetic and propionic acids paralleling caecal enlargement, although this was not always significantly different from the controldiet group (Table 5). Total caecal butyric acid content was still significantly less than control values for rats fed on the diet containing potato starch (Table 5).

Caecal microbial enzyme activities per g caecal content were generally decreased for rats fed on the ARS-containing diets, with $\beta$-glucuronidase (decreased approximately $80 \%$ ), nitroreductase (decreased 50-80\%) and ammonia formation (decreased 60-75\%) showing a pronounced loss of activity in both treatment groups (Table 6). Calculation of enzyme values per total caecum showed that both ARS -containing diets significantly increased $\beta$ glucosidase activity, whereas other microbial enzyme functions remained largely unaltered (Table 7). 
Table 6. Caecal bacterial enzyme activities ( $\mu \mathrm{mol} / \mathrm{h}$ per $\mathrm{g}$ caecal content) assayed anaerobically at $37^{\circ}$, from rats fed on various starch-based diets $\dagger$

(Mean values and standard deviations for five rats)

\begin{tabular}{|c|c|c|c|c|c|c|c|c|}
\hline \multirow[t]{2}{*}{ Dietary starch... } & \multicolumn{2}{|c|}{ Maize } & \multicolumn{2}{|c|}{ Amylomaize } & \multicolumn{2}{|c|}{ Potato } & \multirow[b]{2}{*}{$F_{2,12}$} & \multirow[b]{2}{*}{$P$} \\
\hline & Mean & SD & Mean & SD & Mean & SD & & \\
\hline Ammonia formation & $2 \cdot 1$ & $0 \cdot 4$ & $0 \cdot 5^{* *}$ & $0 \cdot 1$ & $0 \cdot 9^{* *}$ & $0 \cdot 1$ & $11 \cdot 0$ & $* *$ \\
\hline $\begin{array}{l}\beta \text {-Glucosidase } \\
\quad(E C 3.2 .1 .21)\end{array}$ & $10 \cdot 0$ & 0.6 & $7 \cdot 6^{*}$ & $1 \cdot 1$ & $6 \cdot 3$ & 0.4 & $5 \cdot 9$ & * \\
\hline $\begin{array}{r}\beta \text {-Glucuronidase } \\
(E C \text { 3.2.1 } 31)\end{array}$ & $27 \cdot 6$ & $1 \cdot 6$ & $4 \cdot 7 * * *$ & $0 \cdot 5$ & $3 \cdot 4^{* * *}$ & 0.5 & $180 \cdot 0$ & *** \\
\hline $\begin{array}{l}\text { Nitrate reductase } \\
(E C 1.7 .99 .4)\end{array}$ & $1 \cdot 2$ & $0 \cdot 1$ & $1 \cdot 2$ & $0 \cdot 6$ & 0.3 & $0 \cdot 1$ & $2 \cdot 2$ & NS \\
\hline Nitroreductase & 0.92 & 0.05 & $0 \cdot 48^{* *}$ & 0.07 & $0 \cdot 20 * * *$ & $0-02$ & $53 \cdot 4$ & $* * *$ \\
\hline
\end{tabular}

NS, not significant.

Mean values were significantly different from those for the maize starch group (ANOVA): ${ }^{*} P<0.05$, ** $P<0.01,{ }^{* * *} P<0.001$.

$\dagger$ For details, see p. 598.

Table 7. Total activity ( $\mu$ mol/h per total content) of caecal bacterial biotransformation enzymes, assayed anaerobically at $37^{\circ}$, from rats fed on various starch-based diets $\dagger$

(Mean values and standard deviations for five rats)

\begin{tabular}{|c|c|c|c|c|c|c|c|c|}
\hline \multirow[t]{2}{*}{ Dietary starch ... } & \multicolumn{2}{|c|}{ Maize } & \multicolumn{2}{|c|}{ Amylomaize } & \multicolumn{2}{|c|}{ Potato } & \multirow[b]{2}{*}{$F_{2,12}$} & \multirow[b]{2}{*}{$P$} \\
\hline & Mean & SD & Mean & $S D$ & Mean & SD & & \\
\hline Ammonia formation & $1 \cdot 6$ & 0.4 & $1 \cdot 3$ & $0 \cdot 3$ & $6 \cdot 5^{* *}$ & $1 \cdot 7$ & $8 \cdot 2$ & ** \\
\hline $\begin{array}{l}\beta \text {-Glucosidase } \\
\quad(E C 3.2 .1 .21)\end{array}$ & $7 \cdot 1$ & $1 \cdot 1$ & $18 \cdot 4^{*}$ & $3 \cdot 3$ & $45 \cdot 3 * * *$ & $4 \cdot 1$ & $39 \cdot 5$ & $* * *$ \\
\hline $\begin{array}{r}\beta \text {-Glucuronidase } \\
(E C 3.2 .1 .31)\end{array}$ & $19 \cdot 7$ & $3 \cdot 2$ & $11 \cdot 7$ & $2 \cdot 2$ & $23 \cdot 9$ & $3 \cdot 2$ & $4 \cdot 5$ & * \\
\hline $\begin{array}{r}\text { Nitrate reductase } \\
(E C \text { 1.7.99.4) }\end{array}$ & 08 & $0 \cdot 2$ & $2 \cdot 9$ & $1 \cdot 5$ & $1 \cdot 8$ & 0.5 & $1 \cdot 3$ & NS \\
\hline Nitroreductase & 0.7 & $0 \cdot 1$ & $1 \cdot 2$ & 0.2 & $1 \cdot 4$ & $0 \cdot 1$ & 6.7 & $*$ \\
\hline
\end{tabular}

NS, not significant.

Mean values were significantly different from those from maize-starch group (ANOVA): ${ }^{*} P<0 \cdot 05$, ** $P<0 \cdot 01, * * * P<0.001$.

$\dagger$ For details, see p. 598

\section{DISCUSSION}

The hind-gut microflora produces a wide range of enzymes capable of degrading dietary polysaccharides which gain access to the hind-gut (Salyers \& Leedle, 1985), including starch (MacFarlane \& Englyst, 1986). The results from the present study demonstrate that diets containing a proportion of uncooked ARS can modify caecal bacterial metabolism in the rat large intestine. These changes are presumably related to the degradation of undigested carbohydrate by the microflora. Final body-weight was unchanged in both groups of rats fed on the ARS-containing diets, although an increase in food intake was observed $(14 \%$ increase for the amylomaize group, $36 \%$ increase for the potato starch group; results not 
shown), suggesting adaptation of the animals to the presumably lower energy density of the test diets. SCFA produced by bacterial fermentation (Wolin \& Miller, 1983) of ARS could also have been absorbed from the gut and contributed to the metabolic pool of the host (Cummings et al. 1986). It is of interest, however, that the two starches gave quite distinct changes in the profile of SCFA present in caecal contents. Both materials significantly decreased the concentration of minor, branched-chain SCFA in the caecum, which is reported to be associated with a suppression of protein fermentation by the gut flora (MacFarlane \& Allison, 1986; MacFarlane et al. 1986). However, while amylomaize ingestion increased propionic and butyric acid levels, potato starch decreased the concentration of SCFA in hind-gut contents.

The decrease in SCFA in the potato-starch-fed animals may further indicate dilution of the gut contents by residual dietary starch or changes in osmolarity of the gut contents. Other workers have shown that the final ratio of these acids reflects the identity of the particular carbohydrate source undergoing anaerobic degradation (Cummings \& Englyst, 1987), which may account for the different molar ratios of SCFA observed in the present feeding study. SCFA are physiologically active in the large intestine and butyrate, in particular, is thought to be essential for the normal functioning of epithelial cells lining the bowel (Roediger, 1980, 1982). In this context the increased butyrate concentration observed with the amylomaize-supplemented diet, and the decrease in the potato starch ration, may have potential long-term consequences for the colon.

Both starch supplements significantly lowered the $\mathrm{pH}$ of the caecum, in agreement with observations by other workers (Berry \& Fisher, 1985), with an associated decrease in the apparent rate of formation and concentration of ammonia. These findings again support the increased utilization of carbohydrate as a microbial energy source with decreased reliance on protein degradation (deamination) and fermentation (MacFarlane \& Allison, 1986; MacFarlane et al. 1986). Vince \& Burridge (1980) reported that ammonia formation by Gram-negative anaerobic bacteria was strongly inhibited by the addition of simple fermentable carbohydrates to an in vitro incubation system, supporting this hypothesis. Catabolite repression or inhibition may be responsible for this inhibitory effect, and could thereby decrease the amount of ammonia available to exert a toxic effect on local tissues (Visek, 1978; Targowski et al. 1984). It has also been suggested that a lowering in $\mathrm{pH}$ of the large intestinal contents by fermentable dietary residues prevents the degradation of bile acids or cholesterol to co-carcinogenic agents active in the bowel (Thornton, 1981; Van Dokkum et al. 1983).

Bacterial metabolism of a number of model xenobiotic compounds was decreased by the two resistant starches, although the effects appeared influenced less by the quantity of ARS present in the rations than the origin of the starch. $\beta$-Glucuronidase activity exhibited a particularly pronounced decrease in activity. Diet-related decreases of this type are postulated to play an important role in modulating the formation of bacterial products in the large intestine, particularly for substances which require enterohepatic recirculation in order to express their toxic properties (Rowland et al. 1985). Such changes may result from the selective repopulation of the large intestine by micro-organisms relatively deficient in the enzyme activities assayed in the present study. Alternatively, the $\mathrm{pH}$ of the contents may directly inhibit some activity of the enzymes measured in this study (A. K. Mallett, C. A. Bearne and I. R. Rowland, unpublished results).

In conclusion, the uncooked ARS investigated in the present study influenced a number of bacterial metabolic processes when fed to the rat. These changes may arise as a consequence of the utilization of starch as a fermentable bacterial substrate in the large intestine. 
The present study was funded by the UK Ministry of Agriculture, Fisheries and Food, to whom A. K. M, C.A. B, I. R. R and P. J. Y express thanks. Hylon VII amylomaize starch was a gift from National Starch \& Chemical, Manchester. The authors thank S. Gaskin, S. Jones and N. Morley for technical assistance with this work.

\section{REFERENCES}

Berry, C. S. (1986). Journal of Cereal Science 4, 301-314.

Berry, C. S. \& Fisher, N. (1985). Abstracts of the XIII International Congress of Nutrition, Brighton, p. 70.

Björck, I., Nyman, M., Pedersen, B., Siljeström, M., Asp, N.-G. \& Eggum, B. O. (1986). Journal of Cereal Science 4, 1-11.

Cummings, J. H. \& Englyst, H. N. (1987). American Journal of Clinical Nutrition 45, 1243-1255.

Cummings, J. H., Englyst, H. N. \& Wiggins, H. S, (1986). Nutrition Reviews 44, 50-54.

Englyst, H. N. \& Cummings, J. H. (1985). American Journal of Clinical Nutrition 42, 778-787.

Englyst, H. N. \& Cummings, J. H. (1986). American Journal of Clinical Nutrition 44, 42-50.

Englyst, H. N. \& Cummings, J. H. (1987). American Journal of Clinical Nutrition 45, 423-431.

Englyst, H. N., Wiggins, H. S. \& Cummings, J. H. (1982). Analyst 107, 307-318.

Flourie, B., Florent, C., Jouany, J.-P., Thivend, P., Etanchand, F. \& Ramband, J.-C. (1986). Gastroenterology 90 , 111-119.

Holdeman, L. V. \& Moore, W. E. C. (1973). Anaerobe Laboratory Manual, 2nd ed. Blacksburg, Virgina: VPI Anaerobe Laboratory.

MacFarlane, G. T. \& Allison, C. (1986). FEMS Microbiology Ecology 38, 19-24.

MacFarlane, G. T., Cummings, J. H. \& Allison, C. (1986). Journal of General Microbiology 132, 1647-1656.

MacFarlane, G. T. \& Englyst, H. N. (1986). Journal of Applied Bacteriology 60, 195-201.

Mallett, A. K., Rowland, I. R. \& Bearne, C. A. (1985). Toxicology 36, 253-262.

Moore, L. V. \& Holdeman, W. E. C. (1975). Cancer Research 35, 3418-3420.

Roediger, W. E. W. (1980). Gut 21, 793-798.

Roediger, W. E. W. (1982). Gastroenterology 83, 424-429.

Rowland, I. R., Mallett, A. K. \& Wise, A. (1985). CRC Critical Reviews in Toxicology 31, 31-103.

Salyers, A. A. \& Leedle, J. A. Z. (1985). In Human Intestinal Microflora in Health and Disease, pp. $129-146$ [J. H. Hentges, editor]. New York: Academic Press.

Snedecor, G. W. \& Cochran, W. G. (1968). Statistical Methods, 6th ed. Ames: Iowa State University Press.

Stephen, A. M., Haddad, A. C. \& Philips, S. F. (1983). Gastroenterology 85, 589-595.

Targowski, S. P., Klucinski, W., Babiker, S. \& Nonnecke, B. J. (1984). Infection and Immunity 43, $289-293$.

Thornton, J. R. (1981), Lancet i, 1081-1082.

Van Dokkum, W., de Boer, B. C. J., van Faassen, A., Pikaar, N. A. \& Hermus, R. J. J. (1983). British Journal of Cancer 48, 109-110.

Vince, A. J. \& Burridge, S. M. (1980). Journal of Medical Microbiology 13, 177-191.

Visek, W. J. (1978). American Journal of Clinical Nutrition 31, S216-S220.

Wise, A., Mallett, A. K. \& Rowland, I. R. (1982). Xenobiotica 12, 111-118.

Wolin, M. J. \& Miller, T. L. (1983). In Human Intestinal Microflora in Health and Disease, pp. 147-165 [J. H. Hentges, editor]. New York: Academic Press. 